\title{
Environmental Laws: To Sue or Not To Sue
}

\author{
Mohd Fadzil Shuhaimi bin Ramli \\ School of Biological Sciences, Quest International University Perak, Malaysia
}

\begin{abstract}
In this paper, some legal issues pertaining to claiming compensation by fishers due to marine pollution are discussed.With exception of damages caused by oil pollution, fishers have to present their grievances in civil court adhering to English common law. In the court of law, the primary concern is whether a plaintiff has the right to sue. Although they may proof locus standi by possessing licenses to fish, that their damages are over and above the general public, proving damages is another obstacle. As is it now, the laws are not compassionate enough to the environmental victims. The existing environmental laws are inadequate to deal with the environmental problems, simply because of their soft approach in the name of encouraging development and protecting the developers.There should be a change in environmental laws in Malaysia, particularly giving due regard to economic losses resulted from the pollution. It is proposed that property rights to be awarded to fishers managing the fisheries resources since it will settle the obstacle in seeking for compensation.
\end{abstract}

Keywords: compensation, locus standi, public property, property rights

\section{Introduction}

Bringing legal suits by individuals against polluters is common and there are cases where the victims were rewarded [1] [2]. In court case concerning Wahab bin Ibrahim and 263 ors V AET Tanker Holding sdn $B h d$., the plaintiff made a loss of income claim under Merchant Shipping (Oil Pollution) Act 1994 (MSOPA, 1994) [3]. They were awarded RM 20,000 as compensation after the Judge Vernon Ong satisfied that they have the right to claim under the law but allowed only 50 plaintiffs to be compensated as the others were unlicensed fishers as such lost their rights. The law, MSOPA 1994 provides the aggrieved persons to claim damages as result of oil pollution caused by the owner of the polluting ship. Unlike Wahab bin Ibrahim's case, the failed claim by fishers caused by coastal reclamation works is illustrated in Mohd Nor bin Jamil and 123 ors $V$ i) Pengerang Independent Terminal Sdn Bhd., ii) Dialog E\& C Sdn Bhd., iii) Kerajaan Negeri Johor. In his judgment, Judge Teo Say Eng dismissed the claim with RM 8,000 cost [4]. Although some of them were allowed to claim since they were licensed fishers, the plaintiffs had failed to prove, inter alia, their right to fish is premised upon their constitutional right or common law right if any or statutory right.

Claiming losses caused by pollution other than oil spill, or other man-made catastrophe by fishers is almost impossible in Malaysia. As is it now, the laws are not compassionate enough to the environmental victims. Ansari [5] said the judicial delineation of tortuous remedy has utterly failed to control environmental pollution and to bring justice to the doorstep of the indigent and poor people. In the court of law, the primary concern is whether a plaintiff has the right to sue in public property damages. It was shown in Ketua Pengarah Jabatan Alam Sekitar \& Anor V Kajing Tubek \& Ors where the court took a more restricted view and denied the native residents locus standi to raise this matter in the court for the following reasons, inter alia; there was no special injury suffered by the respondents over and above the injury common to others [6]. Fishers have no property rights over the sea and its natural resources; so, do they possess the right to claim for compensation for damage of goods that do not belong to them? Fishers are merely given a right to fish by way of licenses [7] within a stipulated period of time [8], where license may be renewed [9], and subjected to conditions as specified by the authority [10]. In Jan De Nul (UK) Ltd. V NV Royale Belge [11] , Judge Moore-Bick concurred with the counselors of the defendant that only those claimants who could show legal ownership or a possessory title to property damaged by siltation could pursue a claim in negligence. Similarly, in the tort of nuisance, Lord Goff in Hunter V Canary Wharf [12] pointed out that an action of private nuisance will usually be brought by a person in actual possession of the land affected, either as the freeholder or tenant of the land in question, or even as a licensee with exclusive possession, but a mere licensee on the land has no right to sue.

This paper is devoted into establishing whether fishers or any other persons aggrieved by the environmental impairment have the right to be compensated for the economic loss incurred. Supposing the aggrieved persons were to sue the polluters and claim compensation, the possible outcome of the trial is discussed in this chapter based on previous courts rulings. According to [13], Malaysia is a common law country, with the same adherence to the doctrine of precedence, which includes the concepts of ratio decidendi, obiter dictum, stare decisi, res judicata, etc., as found in the United Kingdom, most other commonwealth countries, and the United States [14]. Some suggestions to improve and strengthen the environmental legislation 
are also made with the intention of curbing the growing activities of polluters in Malaysia [15], as the present laws are inadequate to deal with the problems.

\section{Laws Relating To Marine Pollution}

Supposing fish death occurs at sea causing loss of income to some fishers, then, which remedy best fit for them to claim compensation? If the catastrophe was caused by oil spill, they may refer to the MSOPA, 1994 which provides a regime of liability and compensation for parties affected by oil pollution [16]. The International Convention on the Establishment of an International Fund for Compensation for Oil Pollution Damage (Fund) was adopted at a Conference held in Brussels in 1971 (entry into force 1978 but later superseded by 1992 Protocol) [17]. Under the first of its purposes, the Fund is under an obligation to pay compensation to States and persons who suffer pollution damage, if such persons are unable to obtain compensation from the owner of the ship from which the oil escaped or if the compensation due from such owner is not sufficient to cover the damage suffered. In Malaysia, the Fund was established under the MSOPA, 1994 where Section 19 (1) stipulates that the Fund shall be liable for pollution damage in any area of Malaysia if the person suffering the damage has been unable to obtain full compensation. However, if the fish death is caused by other pollutants, then the most suitable statutory law to be referred is the Environmental Quality Act 1974 (EQA 1974), which is the principle legislation in Malaysia regulating the prevention, abatement, control of pollution as well as the enhancement of the environment, and is the legislation most often invoked to deter marine pollution in Malaysia [18]. However, unlike the MSOPA, 1994, which ensures that those engaged in the act of polluting the sea have to pay for the cleaning costs as well as compensating those affected by the damage, the EQA 1974 remains an inadequate deterrent and economically inefficient since it does not encompass other societal losses. With the exception of the provisions contained in the MSOPA,1994 pertaining to oil pollution, no other environmental laws in Malaysia give due regard to the damage incurred by the people, let alone providing a proviso for compensation. There is hardly any legislation that provides for civil liability for such pollution, let alone one that spells out the decisive criteria or its consequences [19]. Thus, aggrieved individual or individuals could only resort to the law of torts, which is based on the English common law principles as described in $R V$ Civil Service Appeal Board ex parte Cunningham, where it was held that although there was no statutory duty to give reasons, there was a common law requirement of 'natural justice' to outline sufficient reasons to indicate whether the decision has been lawful [20]. It indicates that, in the absence of statutory laws, common law is referred. Conservatively, a person or a group of persons aggrieved by the damage could summon the polluter and then presenting his or their case before a civil court judge and use the law of torts to go against those responsible for polluting acts.

\section{Legal Issues}

In the court of law, the primary concern is whether a plaintiff has the right to sue. Consequently, various legal issues are discussed below:

\subsection{Private or public property}

The sea and its 'contents' are public property because it possesses the characteristics of non-rivalness and non-excludability [21]. Non-rivalness means when the good is consumed by one individual, another person is not pre-empted from consuming it at the same time, while non-excludability means that preventing others from sharing in the benefits of a good's consumption is not possible. Fisheries resources, mangroves and most environmental goods are public properties or common property, res communis omnium, and nobody has individual rights to them [22].The opposite is private property which refers to exclusive rights over objects or information vested in a single legal entity and individuals or corporations holding such rights can exclude others from the benefits of their property and regulate its use [23]. Moreover, fishing is not a free access entity, given that the public involvement is being restricted by existing statutory laws. Section 8 of the Fisheries Act 1985 (Act 1985), inter alia, prohibits any person operating or allows to be operated a vessel for the purpose of fishing without a valid license, and a penalty for failure to comply with the said provision is stipulated under Section 25 of the same Act 1985 that the offender shall be fined an amount not exceeding RM 20,000 or a term of imprisonment not exceeding two years. Section 13(1) of the Act 1985 empowers the Director-General in matters of issuance, renewal, canceling or suspending any license stipulated under the Act 1985 for reasons of the proper management of the fisheries, but any person aggrieved by his decision may appeal to the Minister (Section 13(4) of the Act 1985). Sometime in 1983, the Department of Fisheries (DOF) ceased to issue new fishing licenses to the public in conjunction with the implementation of New Licensing Policy making fishing a privilege enjoyed by a restricted number of persons.

\subsection{Locus standi}

It is said that once a property is assigned to the ownership, much of the problem relating to compensation can be resolved. Laws are compassionate to the private person holding property rights but when a property is public, it 
does not permit a person claiming compensation on his own, unless he is successful in showing the damages incurred are over and above the general public as illustrated in Jan De Nul (UK) Ltd., when Judge Moore-Bick held that fishers could pursue a claim for public nuisance. Similarly, in Burgess V M/V Tamano, the court pointed out that the commercial fishers and clam diggers have a special interest, quite apart from that of the public in general, to take fish and harvest clams from the coastal waters of the State of Maine. In this respect, fishers are deemed to display sufferance over and above the general suffering as endured by other members of the public. It was noted in Wahab bin Ibrahim's case where the judge allowed only licensed fishers to claim as they were seen to suffer above the general public. Otherwise, no one else is allowed to act on behalf of others due to the strict adherence to the doctrine of locus standi (see Ketua Pengarah Jabatan Alam Sekitar \& Anor V Kajing Tubek \& Ors).

\subsection{Pure economic loss}

Whenever there is an environmental degradation caused by an individual or firm during the production of goods, there will be other individual or firm prone to incur some losses, normally in monetary term. In economic terms, the cost borne by other people is the external cost or externality not accounted for by the people who caused the pollution, whereas the same cost may be termed as pure economic loss in a legal arena. Pure economic loss is specifically dedicated to loss that is not related to physical injury to person or property other than the defective property itself [22] [24], whereas, as pointed out by [25], externalities are present whenever an individual or firm can take an action that directly affects others, but for which it neither pays nor is paid compensation. In dealing with these losses, an economist and a counsellor for the defendant differ, that the former insists externality to be internalized to correct market failure while the latter argues whether the plaintiff has the capacity to claim compensation on such cost. For example, an oil-spill on the beaches caused by an oildrilling company could cause hoteliers to loose guests, fishers losing of income consequential of reduced fish catches, fish consumers having to pay higher fish prices after the perturbation, cockles farmers being denied the prospect of continuing their activities and society losing the benefit of mangroves as they are depleted; are all claiming for pure economic loss except the municipality which is paying the beach clean-up costs claiming the economic loss. With the exception of fishers, as shown in Jan De Nul (UK) Ltd and Burgess, other pure economic loss claimants may face problems in seeking compensation. Nevertheless, in economics, both losses are the same, that they are the externalities borne by other environmental users and preferably included in the total costs of the individual or firm producing the goods.

There is also a problem of claiming pure economic loss. Normally, an infringed private property is an economic loss to the owner; who may ask for compensation. On the other hand, environmental degradation caused by a firm producing paper creates various pure economic losses to the society; such claims may not be welcomed in the court of justice. For instance, The courts in the United Kingdom reject claims for the recovery of loss suffered by a person due to the negligent act of another, if it is a claim for pure economic loss [24], and in some cases recoverable only under narrowly constrained, special conditions [26]. English Common Law does not permit the claims on pure economic loss to be recoverable [27] to avoid the prospect of an incident giving rise to indeterminate claimants asserting indeterminate liabilities even where causation and foreseeability can be established [28]. However, in Malaysia, there was an attempt to depart from English law on this matter, when in 1997, Judge James Fong of the High Court in Dr Abdul Hamid Abdul Rashid \& Anor V Jurusan Malaysia Consultants (sued as a firm) \& Ors [29] said that a claim for pure economic loss can be entertained in an action for negligence giving high hopes to many house buyers. He reasoned that non-allowance of such claim would leave the entire group of subsequent purchasers in this country without relief against errant builders, architects, engineers and related personnel who are found to have erred. He even reaffirmed his judgement on pure economic loss in Steven Phoa Cheng Loon \& ors V Highland Properties Sdn. Bhd. \& ors [30] .Unfortunately, Judge James Fong's assertion was short lived as it was not well received in Pilba Trading \& Agency V South East Asia Insurance Bhd. \& Anor [31], where the High Court Judge Muhammad Kamil, in dismissing the appeal of the appellant for claiming pure economic loss, said that it was a financial or pecuniary loss and did not involve any physical damage or danger of physical damage to the property of the appellant and it was quite distinct from cases of economic loss involving physical damage. Finally, in Arab-Malaysian Finance Bhd. V Steven Phoa Cheng Loon \& ors and other Appeals [32] the court of appeal judges verified that Judge James Fong was wrong when he held that as a matter of policy he could award pure economic loss thus bringing back the Malaysian court under the wings of its mentor, the English Common Laws as far as pure economic loss is concerned.

In Algrete Shipping Co. Inc. \& Another V International Oil Pollution Compensation Fund and Others (The "Sea Empress") [33], it was made clear that pure economic loss is non-recoverable in the law of tort, with the exception of fishers. The court of appeal dismissed the case brought by Tilbury (Tilbury is R.J. Tilbury \& Sons (Devon) Ltd. who brought an action against the owners of Sea Empress) for loss of profit since it was unable to receive supply of whelks from the fishers who were banned by the authority from fishing as a result of 
oil spill from a ship 'Sea Empress' owned by Algrete Shipping Co. Inc. The Tilbury loss was incurred on land far away from the contaminated area and thus termed by the court as secondary economic loss, which was outside the intended scope of a statute which closely focused on physical contamination and its consequences. On the other hand, the court also held that; damage consisting of economic loss might well be recoverable under the statute by persons such as fishers accustomed to fish in the waters which became contaminated; and the interest and losses of such fishers could be very closely related to the physical waters and the physical contamination that occurred.

The Algrete Shipping case tells that while fishers may claim compensation, fish consumers shall not since their losses are secondary economic loss, unconnected and far away from the contaminated area. Mangrove users may then be eligible for compensation if their direct connection with mangroves is recognized, and does not characterize a pure economic loss.

\subsection{Public nuisance}

The word 'nuisance' is derived from the French word 'nuire,' which means to injure, hurt or harm and may be described as an 'unlawful interference with a person's use or enjoyment of land or some right or in connection with it' [34]. Nuisance comes under two categories; a private nuisance which is an act or omission and is an interference with, disturbance of, or annoyance to, a person in the exercise or enjoyment of his ownership or occupation of land or of some easement, profit or the right used or enjoyed in connection with land [35]; and a public nuisance when the interference is with the general right of the public. However, nuisance is not necessary happening on land, as it could also occur elsewhere [36]. In Halsey V Esso Petroleum Co Ltd [37], it was held that unreasonable noises or vibration interferes with one's enjoyment, one's quiet, one's personal freedom, and anything that discomposes or injuriously affects the senses or the nerves.

A public nuisance is an offense under common law [38], and is an unlawful act or omission to discharge a legal duty, which act or omission endangers the lives, safety, health, property or comfort of the public are obstructed in the exercise or enjoyment of any right common to all Her Majesty's subjects [35]. When the sea is infringed by pollution, it is a public nuisance; as is when mangroves are degraded by human actions. In both cases, it is public because it affects many people, but Lord Justice Denning declined to specify how many instead said that a public nuisance is a nuisance which is so widespread in its range is so indiscriminate in its effect that it would not be reasonable to expect one person to take proceedings on his own responsibility to put a stop to it, but that it should be taken on the responsibility of the community at large [39][40]. Action against those causing public nuisance seems to be suited for environmental litigation in the public interest but the common law of England has delimited its scope [5], and is further hampered by the decisions taken in Malaysian courts. In the House of Lords, it was held that it was a fundamental principle of English Law that public rights could only be asserted in a civil action by the Attorney-General as an officer of the Crown representing the public, except where statute otherwise provided, a private person could only bring an action to restrain a threatened breach of the law if his claim was based on an allegation that the threatened breach would constitute an infringement of his private rights or would inflict special damage on him [41]. In Malaysia, although a private person has successfully proved his damage to be special, in the light of Section $8(1)$ of the Government Proceedings Act 1956 (Act 359, Revised 1988), an Attorney General consent is mandatory. This decision was made in Koperasi Pasaraya Malaysia Bhd. V Uda Holdings Sdn. Bhd. \& Ors [42] where the high court made the ruling that for the plaintiff to bring an action based on public nuisance, he must satisfies two conditions: (1) the plaintiff must not only prove that he suffered special damages; he must also (2) conform and comply with requirements under Section 8(1) of the Government Proceedings Act 1956 (Act 359, Revised 1988) that stipulates;

\footnotetext{
'In the case of a public nuisance the Attorney General, or two or more persons having obtained the consent in writing of the Attorney General, may institute a suit, though no special damage has been caused, for a declaration and injunction or for such other relief as may be appropriate to the circumstances of the case.'
}

Although Judge Azmel in Koperasi Pasaraya Malaysia Bhd. made no reference to Pengarah Jabatan Alam Sekitar, the issues of right to bring action and locus standi in the latter are analogous. To summarise, in public nuisance, an individual can bring an action only when he has the locus standi on the matter raised. As reaffirmed by the Court of Appeal in Pengarah Jabatan Alam Sekitar, an individual's representation in the court be expelled if he does satisfy two conditions that constitute locus standi; (1) obtaining the consent of Attorney General as he is the guardian of the public interest and it is he alone who can enforce the law [43]; and (2) provide prove that his damage is special, i.e. over and above the damage incurred by the others. A similar requirement is also acknowledged in Koperasi Pasaraya Malaysia Bhd. 


\subsection{Negligence}

Negligence can be proved to have been committed by the defendants if their actions depart from the normal conduct that would have been expected from others doing the same tasks. In it barest and most practical form, negligence has been defined by Judge Baron Alderson in Blyth v Birmingham Waterworks [44] as 'the omission to do something which a reasonable man, guided upon those considerations which ordinarily regulate the conduct of human affairs, would do, or doing something which a prudent and reasonable man would not do'. For example, in Foo Fio Na V Hospital Assunta \& Anor [45], a defendant doctor was found to be in negligence by the High Court for failing to exercise the care and skill of an ordinary competent practitioner in that profession. According to [46], "negligence" refers to civil liability, in whatever system, for unintended harm, where this is caused by someone's failure to meet the required standard of competence. In Halsbury's Laws of England 3rd Ed. Vol. 28 pages 1 and 2 under the sub-heading "meaning of negligence" appears the following passage;

\footnotetext{
"Negligence is a specific tort and in any given circumstances is the failure to exercise that care which the circumstances demand. What amounts to negligence depends on the facts of each particular case, and the categories of negligence are never closed. It may consist in omitting to do something which ought to be done or in doing something which ought to be done either in a different manner or not at all...The degree of care required in the particular case depends on the accompanying circumstances, and may vary according to the amount of risk to be encountered."
}

In practice, proving negligence on the manner of which the reclamation works were carried out is difficult, although not impossible. It should be borne in mind that negligence per se is not a cause of action [47]. To succeed in a negligence action, the plaintiff must be able to demonstrate that a duty of care is owed to him by the defendant; that the duty has been breached; that the damage of which he complains was caused by that breach of duty (causation) and that damage of that kind was a reasonably foreseeable consequence of the breach of duty [48] . In Eng Thye Plantations Bhd. V Lim Heng Hock \& Ors [1] , the Court of Appeal reiterated that for an action in negligence to succeed, the plaintiff had to establish that the defendant owed them a duty of care, that the duty was breached and that the breach occasioned harm that was not remote. In relation to environmental torts, [5] provided three conditions that needed to be satisfied to bring an action in negligence against a polluting act. They are: (i) it has to be proven that the plaintiff suffered some damage due to the polluting act of the defendant; (ii) it has to be established that there was a duty not to pollute, and there was breach of the duty; and (iii) it will have to be proven that statutory authority, if any, in the form of a license or otherwise, does not exonerate the defendant from the liability.

\subsection{Proof of damage by pollution}

It is settled in law where a plaintiff brings an action for damages, he must prove it and before he can recover; he has to discharge the burden of proving both as to the fact of damage and as to the amount [49]. In Wahab bin Ibrahim, the High Court judge only awarded loss of income of five days since the plaintiffs could not prove more days.Similarly in Mohd Nor bin Jamil , a mere police report does not constitute proof of their losses and the judge dismissed the claim.

\section{The Remedy}

There is no statutory law that permits such compensation measures except when the damage is caused by oil at sea. In the USA, the designated trustee of natural resources can seek claim through Comprehensive Environmental Response, Compensation and Liability Act of 1980 (CERCLA 1980) for injuries to natural resources resulting from a release of a hazardous substance and to recover monetary damages from the responsible party [50]. Private individuals cannot make claim for environmental damages under CERCLA 1980 but may proceed with common law actions, such as public nuisance, private nuisance, trespass and actions under the Public Trust Doctrine. The European Community (EC) also seems to adopt similar measures, allowing private individuals to seek remedial under Common Law [51] [52].

The existing environmental laws are inadequate to deal with the environmental problems, simply because of their soft approach in the name of encouraging development and protecting the developers. Polluters are made to pay less than the damage caused. Penalties stipulated under the EQA 1974 do not reflect the actual cost, but are ambiguously set at a certain maximum level, although Section 47 of the EQA 1974 does provide the Director General power to recover the clean-up costs from the concerned polluters. Still, the costs that are being discussed here, the human costs, are at distance from the Malaysia's statutes. In Japan, a highly industrialized country, its environmental laws are exemplar of laws compassionate to people. It is compassionate because of the 1996 law concerning the Settlement of Environmental Pollution Disputes (1996 
SEPD), to settle environmental pollution disputes as an alternative to civil trials that were not deemed satisfactory to victims since: (1) they must establish a cause-effect relationship, which was very difficult; (2) a large sum of trial costs was required; and (3) trial proceedings were rigid and a long time was required before a final judgement [53]. The 1996 SEPD was enacted following the prescribed responsibility of the State to take necessary measures to implement effectively conciliation, mediation, arbitration and adjudication with regard to disputes related to environmental pollution, and take other necessary measures to smoothly resolve problems arising from environmental pollution as stipulated under Article 31 of the Basic Environmental Law of Japan. The dispute settlement process requires both parties to agree to succumb to remedies of any of the measures with the exception of adjudication process where the 1996 SEPD gives a certain legal effect to a judgment of an adjudication committee unless an appeal to the judicial court is made within 30 days after the adjudication. The adjudication committee will establish whether: (1) cause-effect relationship in legal terms exists between the alleged harmful act and the damage in an environmental pollution case; and (2) a party is responsible for the monetary compensation for an environmental pollution damages case, and the amount of compensation thereof. With the enactment of such measures, Japan has successfully resolved 1,661 disputes or 96.3\% of the total environmental complaints between 1970 and March 2001 and more importantly had opened up quick and just settlement avenues for the environmental victims and polluters alike. Malaysia should also promote such a move, turning away from the judicial complexity of claiming compensation in civil courts by inserting provisions into the present statutes or enacting a new one that perhaps could provide quick and just remedies. Japan's remedies are society-friendly, and following its example could bring justice to poor environmental victims. Moreover, polluters are accommodated as well since they have to voluntarily accept the settlement processes.

There should be a change in environmental laws in Malaysia, particularly giving due regard to economic losses resulted from the pollution. The fundamental issue here is justice, followed by the rights to live in a better environment. The principle that the harmed person should be compensated should be upheld in a society where justice is paramount. The Polluter Pays Principle (PPP), as adopted by many countries, including Malaysia's environmental laws, has been narrowly defined not to include harms or costs to human beings. Many advocates of market-based instruments misuse the economic theory by redefining the concept of costs and damage to apply to things rather than to people [54]. As such, laws enacted to prevent pollution do not include the rights of harmed people to claim compensation for their losses. The inadequacy of the PPP is acknowledged by the Supreme Court of India in Enviro-Legal Action [55] when it stressed that people should be compensated as well. Therefore, the environmental policy makers should accept the broad definition of PPP so that laws enacted not only penalize polluters to pay for clean-up costs, they also provide some room for people to claim compensation for their losses.

\section{Conclusion}

Environmental problems persist as long as no one has the legal private rights over an environment. For economists, the conventional starting assumption is that all forms of environmental problems are ultimately property problems and that given the right set of property rules, environmental problems would be selfremediating [56]. If property right is clearly assigned to any of the disputing parties, Coase's Theorem [57] would be appropriate. Coase's Theorem proposes that proper assignment of property rights to any good, even if externalities are present, will allow bargaining between the affected parties such that an efficient solution can be obtained, regardless of which party is assigned those rights [21]. However the model's prediction of an efficient outcome depends on two very limiting assumptions: the transactions are costless; and that damages are accessible and measurable. Thus, for the theory to hold in practice, at minimum it must be the case that very few individuals are involved on either side of the market.

Usually, where negotiation has failed between the two parties, legal action is inevitable. It failed because there is no clear property rights assignment, that is, whether the polluters have acquired the rights to pollute or fishers having rights of fishing resources in the area. When both parties believe each has the right either to pollute or to have clean air, then the difficulties emerged [58]. Supposing through government's intervention, fishers, being represented by a legitimate association are given the right of fishing in an area, then negotiation between the two conflicting parties is feasible. In this example, it holds since the polluters are few, so is the affected party being represented by an association acting on their behalf and fish are marketable goods. Since fishers have the right to the fisheries resources, the polluters will have to bribe them in monetary terms to be able to proceed with their works, and Coase's Theorem tells that if the polluters are liable for the damage caused, the amount imposed on them will be the benefit loss of fishers. They will continue to proceed provided the benefit gains from their activities are higher than the amount of bribe offered together with other production costs. Unless the liability is higher than the cost of pollution abatement, they will continue to pollute and pay bribes to fishers. On the other hand, if the revenues of the remaining undamaged fisheries resources are lower than the total cost of fishing, it is profitable for fishers to stop fishing altogether and thus accepting bribes from 
the polluters. In this situation, both fishers and the polluters are in good bargaining power that both parties profit from their actions.

If government does not intervene, no one is assigned the property rights. Bargaining between the two parties is unattainable. Unless the polluters, due to their own conscience, social responsibility or morality, help voluntarily relieve fishers of their hardship, then the questions of property rights and compensation need be answered by the court system. Initially, those answers are reviewed using stipulated provisions under the statutory laws, but where such provisions are absent or inadequately satisfying the aggrieved party, the Common Law in the civil court system is sought. Common Law works best when the number of parties in dispute is small. When a number of parties involved in a dispute is large, and the circumstances are common, the inefficiency is more appropriate to be corrected by the statutory laws. Therefore, without government intervention, fishers are forever victimized by these circumstances. They do not hold individual right to the fisheries resources but only public right, provided, of course, if the statutory laws explicitly address the question of property rights and compensation. Unfortunately, this is not the case.

In fisheries, there has been a suggestion by [59] to establish property rights to fish stocks but for the purpose of improving fisheries management, where, according to him, the owner of a fish stock has a strong incentive to limit fishing to whatever level maximizes profit, whether he cashes in the profit by fishing himself or by selling or leasing to others the right to do so. Assigning property rights to fishers is not new, as it has already been applied in most developed countries, such as Japan, where fisher's cooperatives have been given exclusive rights to inshore resources [60]. In England, clubs own the right to fish along some rivers and they protect their "beats" from pollution [61]. Property rights are important not only for the betterment of fisheries management, but for the protection of the rights itself, since laws are more compassionate towards those owners of the properties. Moreover, with property rights in hand, an owner and a polluter may exercise the Coase's Theorem.

If government does not intervene and no one is assigned the property rights, then aggrieved individuals must now seek for compensation, since amicable negotiation is inaccessible. If compensation is asked for damages on private property, as illustrated earlier, the plaintiff may be successful since the law is compassionate on such claims. However, fisheries resources and mangroves are all public properties for which bringing action against the polluters is the prerogative of Attorney-General. However, in cases where the government itself has a stake in the polluting company, the situation will put the Attorney-General in a dilemma. It is difficult to imagine an Attorney General to drag a government - interest company into a court for causing a public nuisance. This is because the Attorney-General is entwined in the Government as its lawyer and when the Government is sued, it is the Attorney-General's chamber that defends it [62]. Fishers are, however, exceptional, that they may successfully demonstrate their damages are over and above the damages incurred by general public by virtue of their right to fish with licenses issued by the authority. With this privilege, they are able to prove locus standi as well, the condition gravely demanded by the courts in Malaysia.

\section{Acknowledgment}

The author would like to express his gratitude, in general to the Quest International University Perak and in particular to the Dean of the Faculty of Integrative Sciences and Technology for their support and encouragement during the preparation of this paper.

[1]. (2001) 4 MLJ 26 (Eng Thye Plantation Bhd V Lim Eng Hock \& Ors)

[2]. (1992) 4 MLJ 2299 (Woon Tan kan \& Seven Ors V Asian Rare Earth Sdn Bhd)

[3]. (2014) 10 CLJ (Wahab bin Ibrahim and 263 ors V AET Tanker Holding sdn Bhd.)

[4]. [4] (2012) 22ncvc-532-12 Dalam Mahkamah Tinggi Malaya Di Johor Bahru Dalam Negeri Johor, Malaysia Guaman Sivil

[5]. Ansari, A. H., Environmental protection through law of torts: a critical appraisal, Malayan Law Journal Articles, 4 (81), 2000

[6]. (1997) 3 MLJ 23 (Ketua Pengarah Jabatan Alam Sekitar \& Anor v Kajing Tubek \& Ors)

[7]. Section 11 (1) of Fisheries Act 1985 (Act 317)

[8]. Section 14 (1) of Fisheries Act 1985 (Act 317)

[9]. Section 13 (1) of Fisheries Act 1985 (Act 317)

[10]. Section 10 (1) to (3) of Fisheries Act 1985 (Act 317)

[11]. (2000) 2 Lloyd's Rep 700 (Jan De Nul (UK) Ltd. V NV Royale Belge) (HL) (1997) AC 655 (Hunter V Canary Wharf)

[12]. Mohammad, N., An overview of the environmental justice systems in Malaysia and Bangladesh.

[13]. International Journal of Academic Research, 6 (2), 2014

[14]. Del-Bove, M. C., \& Francoz-Terminal, L., How common is the Common Law? Some differences and dimilarities in British and American Superior Court decisions. Alicante Journal of English Studies, 28, 2015, 59-82.

[15]. Utusan Malaysia 8 June 2008, available http://ww1.utusan.com.my/utusan/info.asp?y=2008\&dt=0608\&pub=utusan_malaysia\&sec=impak_alam\&pg=al_01.htm retrieved 24 March 2017

[16]. Kamaruzzaman, J. A., \& Zain, A. M., Coral Bay shore zones tar ball distribution, Procedia Engineering, 148, $2016,437-443$.

[17]. Available on-line at http://www.imo.org/en/About/Conventions/ListOfConventions/Pages/International-Convention-on-theEstablishment-of-an-International-Fund-for-Compensation-for-Oil-Pollution-Damage-(FUND).aspx retrieved 12 March 2017. 
[18]. M. Mustafa \& M. Ariffin, The application of law on pollution control towards marine biodiversity conservation in Malaysia. In Proceeding of International Conference on Environment and BioScience. Singapore, 2011.

[19]. C.S. Chin, Liability under the rule in Rylands and Fletcher in Malaysia. Malayan Law Journal Article, 3 (1), 2003.

[20]. Nik Mahmod, Nik Ahmad Kamal bin and Yaqin, Anwarul, Reasons in administrative decision-making : The reach of judicial review ability in Malaysia, The Malayan Law Journal Articles. 4 (96), 2003.

[21]. S. J. Callan and J.M. Thomas, Environmental economics and management: Theory, policy, and applications (The Dryden Press, U.S.A., 2000)

[22]. P. Wetterstein, Harm to the environment: The right to compensation and the assessment of damages (Clarendon Press, Oxford, 1997)

[23]. Kameri-Mbote, Annie Patricia and Cullet, Philippe, Agro-biodiversity and international law- a conceptual framework, Journal of Environmental Law, 11 (257), 1999.

[24]. 24] A. M Matta, Claimability of economic loss: Malaysia takes a stand amid Inconsistencies. Malaysian Law Journal, 4 (178), 2003.

[25]. J. Stiglitz, and N. Driffill Economics (W W Norton, New York, 2000)

[26]. Jansen, N.,Duties and rights in negligence: A comparative and historical perspective on the European law of extra contractual liability, Oxford Journal of Legal Studies, 24(443), 2004.

[27]. (1990) 3 All ER 711 at 721.(Merlin V British Nuclear Fuels Ltd)

[28]. R. Black, The legal basis for control of imports of animal and plant material into the United Kingdom - does the polluter pay on the high seas?, Environmental Law Review, 53(193), 2003.

[29]. (1997) 3 MLJ 546 (Dr Abdul Hamid Abdul Rashid \& Anor V Jurusan Malaysia Consultants (sued as a firm) \& Ors)

[30]. (2000) 4 MLJ 200 (Steven Phoa Cheng Loon \& ors V Highland Properties Sdn. Bhd. \& ors)

[31]. (1998) 2 MLJ 53 (Pilba Trading \& Agency V South East Asia Insurance Bhd. \& Anor)

[32]. (2003) 1 MLJ 567 (Arab-Malaysian Finance Bhd. V Steven Phoa Cheng Loon \& ors and other Appeals)

[33]. (2003) EWCA Civ 65, (2003) 2 All ER (Comm) 1, (2003) 1 Lloys's Rep 327

[34]. M. Batra, Water rights, in Telbir Singh (ed.), Seminar (Issue number 492). (New Delhi : Malvika Singh, 2000)

[35]. J. F. Clerk, Clerk and Lindsell on the law of torts (London: Sweet \& Maxwell, 1947)

[36]. (1974) 2 NZLR 185 (Paxhaven Holdings Ltd v Attorney General)

[37]. [1961] 1 WLR 683 (Halsey v Esso Petroleum Co Ltd)

[38]. J.F. Archbold, Criminal pleading, evidence and practice (London: Sweet \& Maxwell, 2002)

[39]. (1957) 1 All ER 894

[40]. (1957) 2 QB 169

[41]. (1978) AC 435, (1977) 3 All ER 70, (1977) 3 WLR 300, 141 JP 552, (44 CLJ 6). (Gouriet V Union of Post Office Workers and others)

[42]. (2002) 7 MLJ 174 (Koperasi Pasaraya Malaysia Bhd. V Uda Holdings Sdn. Bhd. \& Ors)

[43]. R. Kanniah, Public participation in the environmental impact assessment process in Malaysia, Malayan Law Journal Articles, 3 MLJA 134, 2000.

[44]. (1856) 11 Exch 781 (Blyth v Birmingham Waterworks)

[45]. (1999) 6 MLJ 738 (Foo Fio Na V Hospital Assunta \& Anor)

[46]. T. Honore, Responsibility and fault (Oregon: Hart Publishing, 1999)

[47]. S. Radhakrishnan, Medical negligence, Malayan Law Journal Articles, 4 MLJA 5, 2002

[48]. C. Pugh, and M. Day, Toxic torts, New Law Journal, Vol. 141, no.6528, 1991 p.1549.

[49]. (1995) 1 MLJ 214 (Kokomewah Sdn. Bhd. V Desa Hatchery Sdn. Bhd.) Available on-line, https://www.epa.gov/enforcement/comprehensive-environmental-response-compensation-and-liability-act-cercla-and-federal retrieved 23 March 2017

[50]. S. Marsden, Strategic environmental assessment in international and European law: A Practitioner's guide, (Earthscan, London, Sterling VA.,2012) Available on-line at http://efface.eu/sites/default/files/EFFACE_Directive\%202004_35_EC\%20on\%20 Environmental\%20liability.pdf retrieved 26 March 2017

[51]. Available on-line at https://www.env.go.jp/en/wpaper/1996/eae250000000040.html retrieved 24 March 2017

[52]. R. E. Cordato, The impossibility of harming the environment, The Freeman: Ideas on Liberty, Vol.52, no.5, 2002.

[53]. WRIT PETITION (C) No.967 OF 1989 Indian Council for Enviro-Legal Action V Union of India \& Others

[54]. D. Cole, Pollution and property: Comparing ownership institutions for environment Protection (Cambridge University Press, 2002)

[55]. E. Schlicht, The Coase mechanism and the iteration argument, Kyklos, 1, 581-582, 2017

[56]. H. R. Varian, Intermediate microeconomics- a modern approach (New York: W.W. Norton \& Company, 1990)

[57]. R. Hannesson, Bioeconomic Analysis of Fisheries. FAO, Rome p.1, 1993

[58]. Y. Asada, Y. Hirasawa, and F. Nagasaki, Fisheries management in Japan. FAO Fish. Tech. Pap. 328. Rome: Food and Agriculture Organization, 1983

[59]. J.H. Adler, Making the polluters pay, .Ideas on Liberty, sv,45, 1995, 167-170.

[60]. Singh, A comparative study of approaches to public interest ligitation (Government of Malaysia/UEM V Lim Kit Siang revisited). Malayan Law Journal Article. 3 (1), 2003 